\title{
The Potential of Delonix regia Pods Powder and Biochar for Remediating Contaminated Soils:A Comparative Study
}

\author{
BOLANLE MORAYO BABALOLA ${ }^{1 *}$ and HAO ZHANG ${ }^{2}$ \\ ${ }^{1}$ Department of Chemistry, Federal University Oye-Ekiti, Ekiti State, Nigeria. \\ ${ }^{2}$ Lancaster University, Lancaster, United Kingdom. \\ ${ }^{*}$ Corresponding author E-mail: bolanle.babalola @ fuoye.edu.ng \\ http://dx.doi.org/10.13005/ojc/360102
}

(Received: November 07, 2019; Accepted: January 03, 2020)

\begin{abstract}
The use of biochar obtained from various sources to effectively immobilize heavy metals in soils have been widely reported, its use to remediate soils may reduce the problem of soil pollution as biochar can reduce the bioavailable heavy metal in soils through adsorption and other physicochemical reactions. Although Delonix regia had been reportedly used in treatment of wastewater, its use for soil remediation has not been investigated in any literature. The efficacy of two amendments (Delonix regia pod powder and hard wood biochar) for the remediation of Tropical soils contaminated with heavy metals (Lead, Copper and Cadmium) were examined under different soil pH, different contaminants concentration, in the presence of organic matter and at different aging period by using $0.01 \mathrm{M} \mathrm{CaCl}_{2}$ extractant. This study gives an overview of the effect of these various conditions on the immobilization of the considered heavy metals by Biochar and Delonix regia pod powder and the result obtained can be used as a solution to remediate soils rich and deficient in organic matter. The immobilization efficiency of both amendments were affected by soil $\mathrm{pH}$ and their performance was generally high irrespective of level of contaminants with biochar having the higher effectiveness. The result also revealed that biochar would be a more suitable choice of treatment in weathered soils while Delonix regia pods performance was better in organic matter rich soil which typify agricultural soils.
\end{abstract}

Keywords: Biochar, Delonix regia pods, Immobilization efficiency, Potential-bioavailable metal, Heavy metals, Extraction method.

\section{INTRODUCTION}

Globally, there is increasingly more cases of soil contamination in recent years as a result of the release of harmful organic and inorganic substances to soils in waste discharge from mining activities, industrial processes, use of waste (manures and biosolids), inadequate management practices in the use of chemicals and pesticides in agriculture, and application of wastewater for irrigation purposes (Zhang et al., 2013; Bolan et al., 2004; Mench et al., 2010). Depending on the type of industries, it is a common occurrence to find heavy metals such as $\mathrm{Pb}, \mathrm{Cd}, \mathrm{Zn}, \mathrm{Cu}, \mathrm{Hg}, \mathrm{As}, \mathrm{Cr}$, as contaminants in soils at industrial sites. Urban soils are not left out as well, various metal species from traffic, paints and many other sources are known to contaminate urban soils (Tchounwou et al., 2012; Todorovic et al., 2014).

This is an Open Access article licensed under a Creative Commons license: Attribution 4.0 International (CC- BY). Published by Oriental Scientific Publishing Company @ 2018

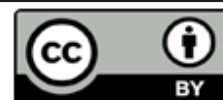


Contaminants such as heavy metals being non-biodegradable show persistence in soils for long term and leads to different associated toxicity in human, animals and plants (Bolan et al., 2014). Contaminated soils not only enhance dietary exposure through the food chain (soilplant-food) Chaney et al., 2004) but are a potential source of pollution to groundwater because toxic heavy in the soils may faulted and fissures zones to contaminate groundwater (El Khalil et al., 2008; Zhao et al., 2009a). An experiment by (Chen et al., 2010) revealed that over $58 \%$ of $\mathrm{Zn}$ were leached into groundwater from composted red soil.

Apart from the harmful effects of metal pollutants to agricultural production and the ecosystem; their presence is also a source of serious threat to human health. According to Petruzzelli, 2012, the European Community Strategy for soil protection identified soil contamination as an important issue for action because of the large no of potentially contaminated soils in Europe.

Contaminants have to be in the soluble form for it to be available and accessible by plants and this means that great effort have to be put in the research to remediate polluted soils since the soluble form have different rate of exchange. A combination of physical, biological and chemical interactions and processes control the availability of the soluble forms of heavy metals to plants and other soil dwelling organisms, in addition, the role played by many soil properties such as $\mathrm{pH}$, organic matter, granulometric composition, forms and occurrence of heavy metals, sorption capacity soil nutrients is crucial to the process of heavy metal sorption and invariably its availability in the soil (Fijałkowski et al., 2012).

Some effort have been directed towards some techniques of soil remediation since conventional methods of soil reclamation such as landfilling and excavation, are often environmentally disruptive and expensive. It will be a very reasonable and good soil management practice not to further introduce any condition or material that could lead to soil pollution, into the ecosystem (beesley et al., 2011). Quite a number of environmentally-friendly and cost effective soil remediation technologies such as chemical immobilization (Kumpiene et al., 2008) and phytoremediation (Memon and Schroder 2009) have been developed to reduce the mobility and availability of heavy metals. Chemical immobilization involves the addition of soil amendments to transform the metal to the solid stable state through complexation, sorption, ion exchange and precipitation and make them present in their less available forms (Ok et al., 2011a). It was also reported that the in situ addition of soil amendments such as compost and lime, could lead to stabilization of heavy metals and thus minimize their uptake by plant (Bolan and Duraisamy 2003; Bolan et al., 2004; Kumpiene 2010; Komárek et al., 2013).

Any carbon-rich solid obtained from the incomplete combustion of biomass is referred to as Biochar (Beesley et al., 2011; Chen and Chen, 2009). Biochar are known to have a large surface area, active organic functional groups and micro-porous structure and therefore many biochars show strong attraction for heavy metals (Chan and Xu, 2009; Inyang et al., 2016; Yuan et al., 2011). It's been shown in many studies that biochar has a high capacity for pollutants in soils and can stabilize heavy metals in contaminated soils (Beesley et al., 2011; Yuan and Xu 2011; (Ippolito et al., 2012). Jiang et al., (2012) reported a decrease by $19.7-100 \%$ and $18.8-77 \%$ in extractable $\mathrm{Cu}$ and $\mathrm{Pb}$ respectively when different doses of biochar amendment was incorporated into soil; result obtained by Karami et al., (2011) revealed that addition of both biochar and compost resulted in a reduction in the level of $\mathrm{Cu}$ and $\mathrm{Pb}$ in the shoot of ryegrass mobility. Similarly, (Méndez et al., 2012) reported a reduction in the bioavailability of several metals ( $\mathrm{Zn}, \mathrm{Ni}, \mathrm{Cd}$ and $\mathrm{Pb})$.

Delonix regia is a flowering plant species from the fabaceae family, it is commonly called the flame tree or Royal Poinnciana; it is a medium sized tree with crooked trunks, rough grey barks and irregularly twisted branches, generally it is considered as agricultural waste as it served no useful purpose other than as shade tree (Mandal et al., 2008). Though, there are limited number of published work on the use of Delonix regia (in the modified and unmodified form) as adsorbent for heavy metals and organic pollutants in solutions Babalola et al., (2019a and 2019b); (Onwuka et al., (2016); Louis et al., (2018); Subramani et al., (2014), Festus et al., 2014) but we have not been able to lay our hands on any showing its ability in contaminated soils.

The objective of this study was to investigate the effectiveness of both Delonix regia pods powder and commercially-sold biochar to remediate heavy metals contaminated soils. 
To accomplish the objective of this work, four experimental conditions were varied, studied or altered: effect of soil $\mathrm{pH}$ was conducted first to determine the aging effect of amendments on its immobilization efficiency; others were effect of contaminants concentration, soil $\mathrm{pH}$ and soil organic matter on the immobilization capacity of the two amendments; a comparison of the efficiency of the amendments for $\mathrm{Pb}, \mathrm{Cu}$ and $\mathrm{Cd}$ immobilization was likewise considered.

\section{MATERIALS AND METHODS}

\section{Materials}

The following metal salts: copper chloride dihydrate, lead and cadmium nitrates were used for the preparation of the metal solution used as contaminants to spike the soil samples. Suspension of Humic acid particles was added to the soils as a form of organic matter. Methylated Spirit, Sodium acetate and ammonium acetate were used in the determination of soil CEC and Calgon solution was used for particle size analysis while the exchangeable metal ion content was determined with Calcium chloride. The Biochar used in this work was obtained from Bodfari Environmental, UK while Delonix regia pods were obtained from Ekiti State University Ado Ekiti, Nigeria. The soil samples used were tropical soils from Nigeria.

\section{Methods}

The Tropical soil samples from Nigeria were collected in transient $(0 \mathrm{~m}, 2 \mathrm{~m}, 4 \mathrm{~m}, 10 \mathrm{~m}$, and $50 \mathrm{~m}$ ) from fields at a depth of $0-20 \mathrm{~cm}$ from three different locations which are shown in Table 1. After collection, the soils collected in transient were thoroughly mixed together, air dried at room temperature, sieved through a $2 \mathrm{~mm}$ mesh sieve and stored in air tight containers for onward shipping to Lancaster University, UK where the laboratory work was carried out. Soil pH, organic matter, cation exchange capacity, extractable metal content and particle size were some of the soil properties that were determined.

The result in Table 1 showed that all the soils were poor in organic matter, we have to add a suspension of humic acid particles ( $2 \% \mathrm{w} / \mathrm{w}$ ) to some of the soil samples in order to investigate the effect of organic matter on the immobilization efficiency of the two treatments considered in this work. Soil organic matter was determined by loss on ignition as described by Konare et al., 2010. Soil pH was measured using a PHM 220 model of the $\mathrm{pH}$ meter calibrated with buffers $\mathrm{pH} 4.0$ and 7.0. The CEC was determined following the procedure adopted by (Lu, 2000). Exchangeable metal content was done with $0.01 \mathrm{M} \mathrm{CaCl}_{2}$ solution and the metal concentrations were analysed by ICP-MS. The maximum water holding capacity was done by filling plants pots with $20 \mathrm{~g}$ soil and watered until the water started dripping from the bottom of the pot. At this point, the pots were covered and left for $24 \mathrm{~h}$ after which certain quantity $(10 \mathrm{~g})$ were weighed into crucibles with known weight. The crucibles and contents were oven dried at $105^{\circ} \mathrm{C}$ for $24 \mathrm{~h}$, allowed to cool and the dried weight of the soil samples were used to calculate the \% maximum water holding capacity Equation 1 for each soil sample.

$\%$ maximum water holding capacity $=\frac{\text { wet weight-dry weight }}{\text { dry weight }} * 100 \%$.

For Particle size analysis, a certain quantity of soil $(20 \mathrm{~g})$ was weighed and mixed thoroughly with $200 \mathrm{~mL}$ of $10 \%$ Calgon solution. The suspension was made to the mark in a $1000 \mathrm{~mL}$ measuring cylinder with $M Q$ water and left to settle at room temperature and then stirred with a plunger; a hydrometer was gently lowered into the suspension at the end of the last stroke of the plunger and timing began. Density reading were recorded at $32 \mathrm{sec}$ and 8 hours. After $8 \mathrm{~h}$ the suspension was decanted and washed until all silts and clay particles were removed leaving mainly the sand particles which was weighed and oven dried at $105^{\circ} \mathrm{C}$ for 48 hours. The soil fractions obtained after converting density measurements to weights were converted to soil texture by using a triangle that was generated by The Soil and Survey of England and Wales Classification. The soil fractions were calculated thus: Silt: Difference between density reading at $32 \mathrm{se}\left(\mathrm{g} / \mathrm{cm}^{3}\right)$ and $8 \mathrm{~h}\left(\mathrm{~g} / \mathrm{cm}^{3}\right)$; Clay: the density reading at $8 \mathrm{~h}\left(\mathrm{~g} / \mathrm{cm}^{3}\right)$; Sand: the weight of the oven dried sand particles (g).

\section{RESULTS AND DISCUSSION}

\section{Soil Properties}

The result of soil properties for all the soil samples collected from the same region in Nigeria is shown in Table 1. They were low in organic matter, have similar texture and their $\mathrm{pH}$ were all below 7. The soils were collected from area were illegal mining activities mainly extraction (without further 
processing on site) was done. The $\mathrm{pH}$ of soils used in this work were between 5.20 to 6.72 . These soils were extremely low in organic matter (0.02 to $0.03 \%)$, this might be as a result of the land use because there is no vegetation cover or agricultural activities on the soil. The CEC of any soil is an indication of its metal retention capacity, the higher the soil CEC the more sites are available for exchange. The values obtained for soil $\mathrm{CEC}$ in this work ranged between 1.43 to $25.22 \mathrm{me} / 100 \mathrm{~g}$ soil. Ilesha soil has the highest CEC of $25.22 \mathrm{me} / 100 \mathrm{~g}$ soil is because the location was initially a cocoa farm before the discovery of gold. Analysis of the soil particles revealed that about 58.2 to $64.7 \%$ of the particles are sand. This had a way of directly impacting on the low water holding capacity of the soil samples which is within 24.34 and $36.02 \%$. Soils with more clay and silt portions have higher water holding capacity.

Table 1: Soil Properties

\begin{tabular}{ccccccccccc}
\hline Soil Samples & Longitude & Latitude & $\mathrm{pH}$ & $\% \mathrm{OM}$ & \multicolumn{3}{c}{$\begin{array}{c}\text { Particle size } \\
\text { Clay }\end{array}$} & \multicolumn{2}{c}{ Texture } & CEC (me/100 g soil) Water H. Capacity \\
\hline IJERO & 5.0742 & 7.8139 & 5.20 & 0.018 & 64.72 & 17.5 & 17.78 & Sandy loam & 1.43 & 24.34 \\
ILESHA & 4.65 & 7.5333 & 6.72 & 0.033 & 59.62 & 12.5 & 27.88 & Loamy sand & 25.22 & 32.73 \\
EKITI & 5.0742 & 7.8139 & 5.40 & 0.026 & 58.2 & 15 & 26.8 & Sandy clay loam & 10.65 & 36.02 \\
IFE & 4.5667 & 7.4667 & 5.65 & 0.018 & 61.94 & 10 & 28.06 & sandy clay loam & 15.27 & 31.93 \\
\hline
\end{tabular}

\section{Aging Effect}

The efficiency of immobilization by each treatment type on each sampling day is calculated based on Equation 2.

Immobilizatin Efficiency $=\mathrm{C}_{\mathrm{a}} / \mathrm{C}_{\mathrm{i}}$

Where $\mathrm{C}_{\mathrm{a}}$ represent the different available concentration between the control samples and the treated samples and $\mathrm{C}_{\text {i }}$ is the available concentration present in the control samples. The available concentration of contaminant is obtained after analysis with the ICP-MS.

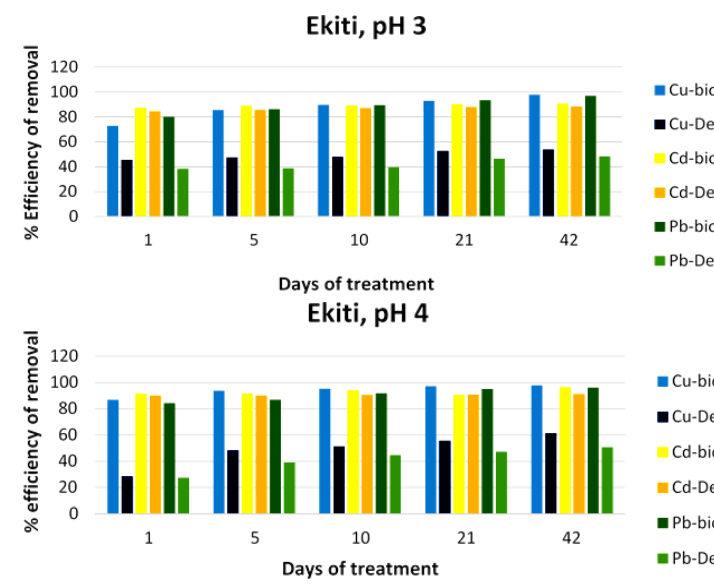

Equilibration time to resemble common field situations are not generally applicable to freshly spiked soils, and because laboratory tests are expected as much as possible to mimic the most realistic situation, effect of contaminant aging in the soil stands to be an important issue to consider in the assessment of metal-contaminated soils so that results obtained could be more realistic and meaningful in the fields (Lanno et al., 2004). Investigating the effect of aging on the immobilization efficiency of each of the treatment materials in this work involved the use of five soil samples, the results obtained from this study are shown in Figure 1.

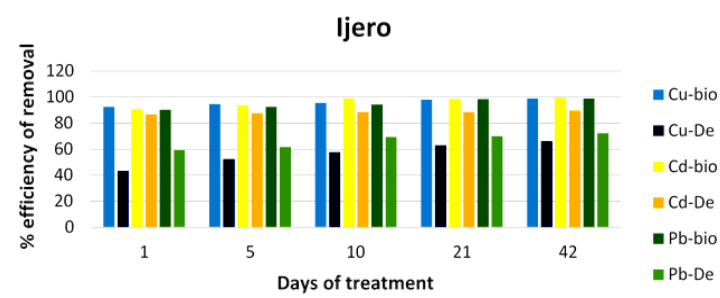

Ife

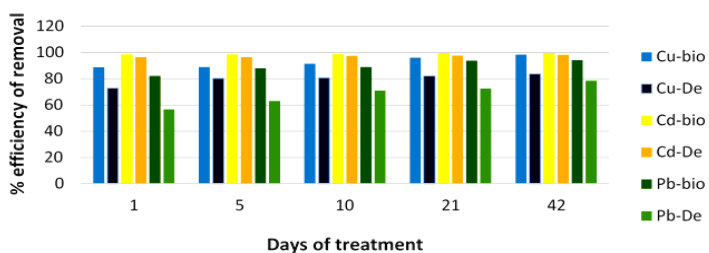

Ilesha

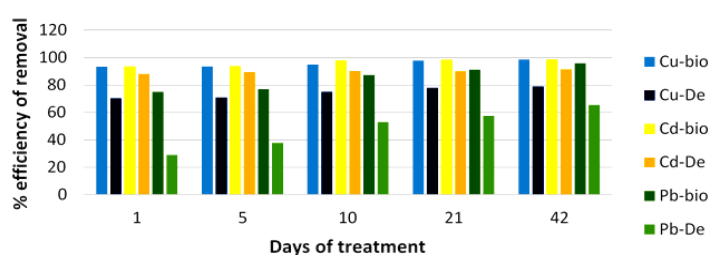

Fig. 1. Effect of aging on the immobilization efficiency of $2 \%(w / w)$ Biochar and $2 \%$ (w/w) Delonix regia for immobilizing metals from contaminated soils 
As the contaminant age in the soils, increasing immobilization efficiency for metal was recorded except (for cadmium in which case it was fairly constant) in all soil samples used in this work. de Barros Amorim et al., (2005), reported a similar observation that aging had no effect on the availability of cadmium in the soil. The increase in efficiency is such that in the low pH soils, the efficiency of immobilization obtained from biochar treatment almost doubled that obtained from Delonix regia treated soils whereas in all other soil samples with moderate $\mathrm{pH}$, biochar had higher efficiency (greater than $80 \%$ ) while Delonix regia recorded $(50 \%)$. This result revealed that, the overall efficiency of immobilization of Delonix regia for copper and lead was moderate $(60 \%)$ while the efficiency of biochar for these contaminants are above $90 \%$. The efficiency of both materials for the immobilization of cadmium is above $90 \%$. This study has shown that more contaminants were being immobilized by the treatment materials (biochar proved to be more effective in treatment of these contaminants) as aging period is increased, indicating that it is more efficient and effective to treat contaminated soils a few weeks after the incident of contamination occurred rather than immediate treatment.

\section{Effect of different concentrations of contaminant}

Soil samples were treated with different concentrations of heavy metal solutions in order to determine the concentration range at which it would be possible to obtain greater immobilization efficiency and thus determine the suitable concentration range for the effective functioning of each of the applied treatments. This aspect of the work was carried out with two different concentrations (referred to as low and high: the low containing a concentration of $100 \mathrm{mg} / \mathrm{kg}$ of lead and copper; $5 \mathrm{mg} \mathrm{Cd} / 100 \mathrm{~kg}$ which is the UK maximum allowable limits of these metals in agricultural soils and high which is a mixture of $300 \mathrm{mg} / \mathrm{kg}$ of lead and copper; $15 \mathrm{mg} \mathrm{Cd} / 100 \mathrm{~kg}$, i.e three times the allowable limits). Three soil samples were contaminated with these concentrations and the results obtained from the study is presented in Figure $2(a$ and $b)$.
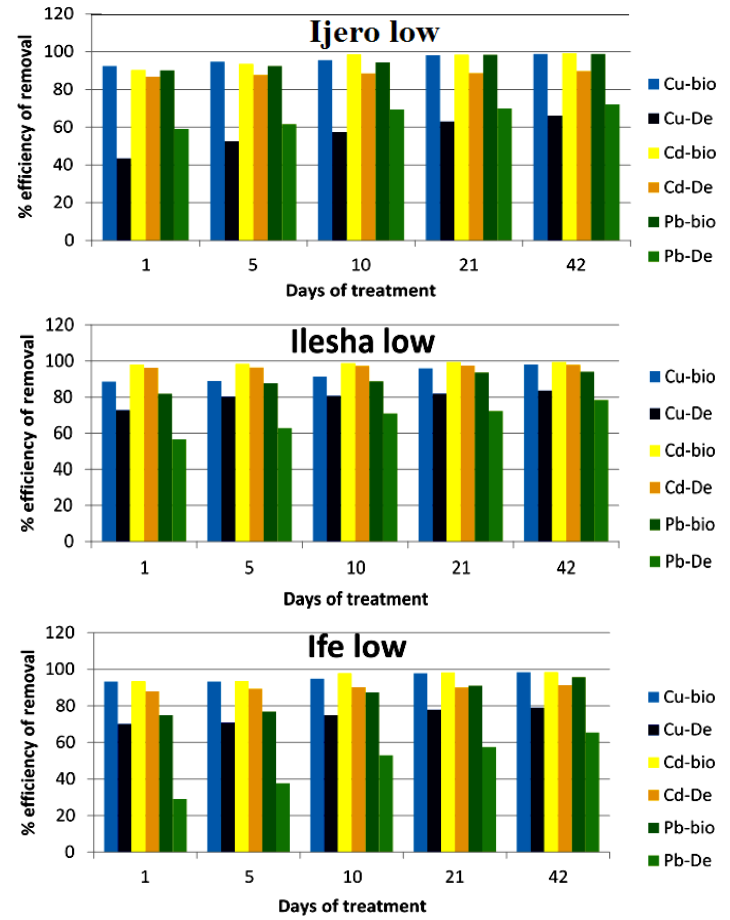

Fig. 2a. Effect of low concentration of heavy metals on the efficiency of $2 \%(w / w)$ Biochar and $2 \%(w / w)$ Delonix regia on immobilization of metals from contaminated soils

The efficiency of the immobilization of copper with biochar in the soil designated as low, was very high, greater than $80 \%$ efficiency was recorded while for Delonix regia, the efficiency recorded were as high as $83 \%$. The two materials under consideration had very high immobilization efficiency for cadmium, $86 \%$ was the lowest efficiency recoded for cadmium in the soils contaminated with low concentration of contaminants. The immobilization efficiency of lead onto biochar was well above $80 \%$ with the exception of Ife low where the lowest immobilization efficiency of $75 \%$ was recorded, the immobilization of lead on Delonix regia was even lower it ranged between $56 \%$ and $78 \%$ except on Ife soil where between $29 \%$ and $66 \%$ were recorded.

In the soil samples designated as high with result shown in Fig. 2b, the efficiency of biochar for copper immobilization was similar to what was recorded in the low soil samples, while Delonix regia showed a decrease efficiency in copper immobilization in high soil samples. 

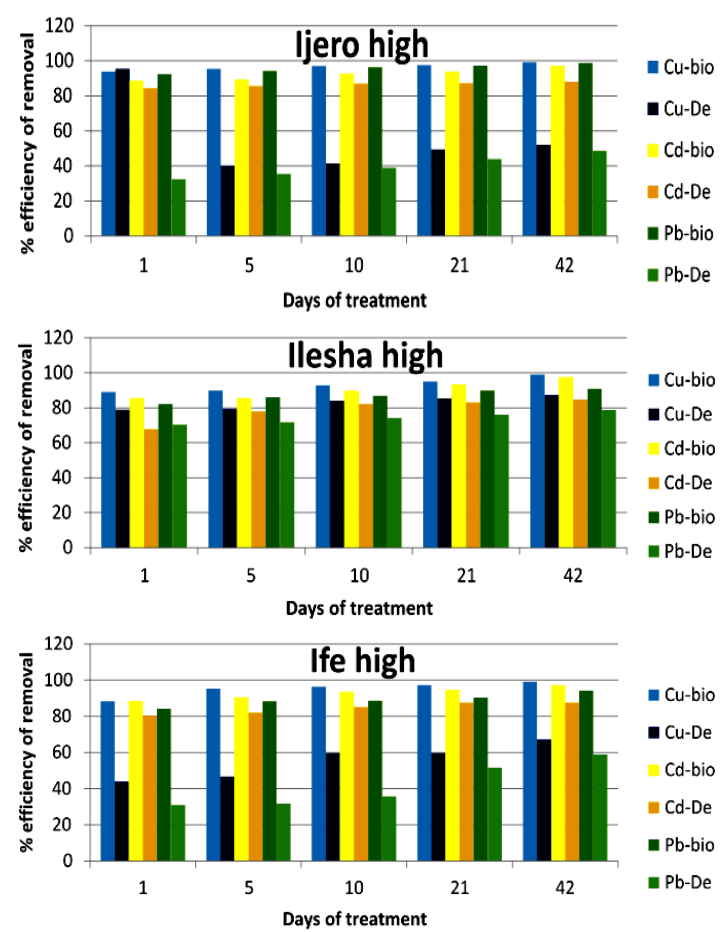

Fig. 2b. Effect of high concentration of heavy metals on the efficiency of $2 \%(w / w)$ Biochar and $2 \%(w / w)$ Delonix regia on immobilization of metals from contaminated soils

Although, the efficiency of biochar for immobilizing cadmium was still very high (above $89 \%)$, it was lower in the high soil than in the low soil samples, similar observation was recorded in the immobilization of cadmium by Delonix regia. For the immobilization of lead by biochar, an efficiency greater than $82 \%$ was recorded in the high soil samples while efficiencies less than half the values recorded in biochar treated soils were recorded in the soils treated with Delonix regia.

The immobilization efficiency of Delonix regia for all the metals differ from one soil sample to another when different concentrations were used; an average efficiency of $70 \%$ was recorded in the low contaminated soil samples while $50 \%$ was recorded as the average in the soils contaminated with higher contaminant concentrations. The immobilization efficiency of biochar seemed not to be affected by changing the concentration of the contaminants, thus its use might not be dependent on contaminant concentration in the soil while Delonix regia whose immobilization efficiency was higher in low soils would be better suitable for treating soils contaminated with low level of contaminants.

\section{Effect of Soil pH on Remediation Process}

The results in Fig. 3 show the effect of soil $\mathrm{pH}$ on the immobilization efficiency of the selected heavy metals by Delonix regia from contaminated soil samples.

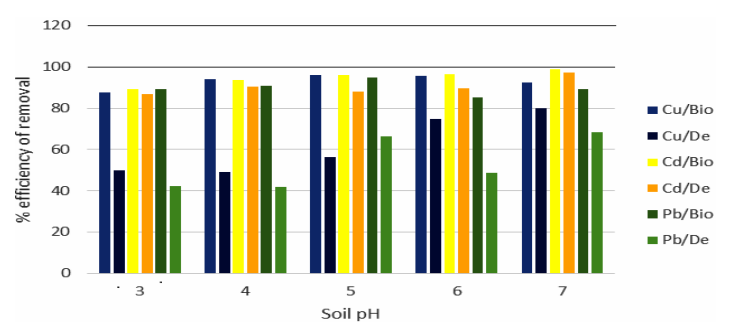

Fig. 3. Effect of soil pH on the immobilization efficiency of $2 \%$ Biochar $(w / w)$ and $2 \%(w / w)$ Delonix regia in soils contaminated with heavy metals

From the results obtained, low soil $\mathrm{pH}$ seemed not have any negative effect on the immobilization efficiency of biochar because amending the soil with biochar increased the soil $\mathrm{pH}$ by a factor. Thus soil $\mathrm{pH} 3$ was increased to $\mathrm{pH} 4$ at which point, treatment with biochar was recorded to have an efficiency of $87.8 \%$ for copper, on soil $\mathrm{pH} 4$, application of biochar increased the soil pH to 5 and the immobilization efficiency of biochar for copper on the soil was increased to $94.1 \%$. The efficiency of biochar for copper was fairly constant at soil $\mathrm{pH} 5$ and 6 and the percentage recorded were $95.9 \%$ and $95.6 \%$ respectively, a reduced immobilization of $92.6 \%$ was recorded on soil with $\mathrm{pH}$ 7. Immobilization of copper unto Delonix regia showed an increasing trend with increase in soil $\mathrm{pH}$, at $\mathrm{pH} 3,50 \%$ immobilization efficiency was recorded, there was no significant change at $\mathrm{pH} 4$; it increased to $56.5 \%$ at pH 5 and then to $74.5 \%$ at pH 6 . At low $\mathrm{pH}$ of 3 , observed copper sorption or immobilization unto Delonix regia was low due to proton competition for active sites, that is the immobilization intensity of heavy metals are reduced when hydrogen ion concentrations are increased (Rieuwerts et al., 2006). It's been reported by Fijalkowsi et al., 2012 that the mobility of metallic elements in soils with neutral or alkaline $\mathrm{pH}$ is lower than in acidic soils and this have a direct implication on the immobilization of the metallic elements in the soil. Thus, when mobility is low (in high pH soils), immobilization is well favoured and vice versa.

The immobilization efficiency of biochar for cadmium had the lowest efficiency in the soil with $\mathrm{pH}$ 3 , in this soil the recorded efficiency is $89.1 \%$ while 
93.74\%; 95.94\%; 96.34\% and 98.88\% were recorded as the immobilization efficiencies in soils at $\mathrm{pH} 4,5$, 6 and 7 respectively. The result obtained from this study showed that greater than $86.6 \%$ immobilizing efficiency was recorded when Delonix regia was used as treatment on contaminated soils. It could be said that Delonix regia is capable of immobilizing cadmium irrespective of soil $\mathrm{pH}$. Immobilization efficiency of biochar for lead in all soil pH considered in this work is greater than $85 \%$ while that of Delonix regia was considerably low in the range of $42.4 \%$ and $68.2 \%$.

From this study, we can generally conclude that the sorption of $\mathrm{Cu}, \mathrm{Cd}$ and $\mathrm{Pb}$ were dependent on soil $\mathrm{pH}$. Soils with low $\mathrm{pH}$ had lower sorption and consequently lower immobilization efficiency which was more prominent or pronounced in the soils treated with Delonix regia because the addition of Delonix regia pods to the soil unlike biochar (led to increase by unity) did not alter the soil $\mathrm{pH}$ and because of the stronger binding properties of biochar for metals.

\section{Effect of soil organic matter}

Organic matter was incorporated into the soils by adding humic acid particles to Ekiti soil $(\mathrm{pH} \mathrm{4)}$ and Ilesha soil $(\mathrm{pH} \mathrm{6)}$. These soils were amended with biochar and Delonix regia in order to study the effect of soil organic matter on the efficiency of removal of metals by these treatment materials (biochar and Delonix regia), the results obtained from the study are presented in Figures 4 and 5.
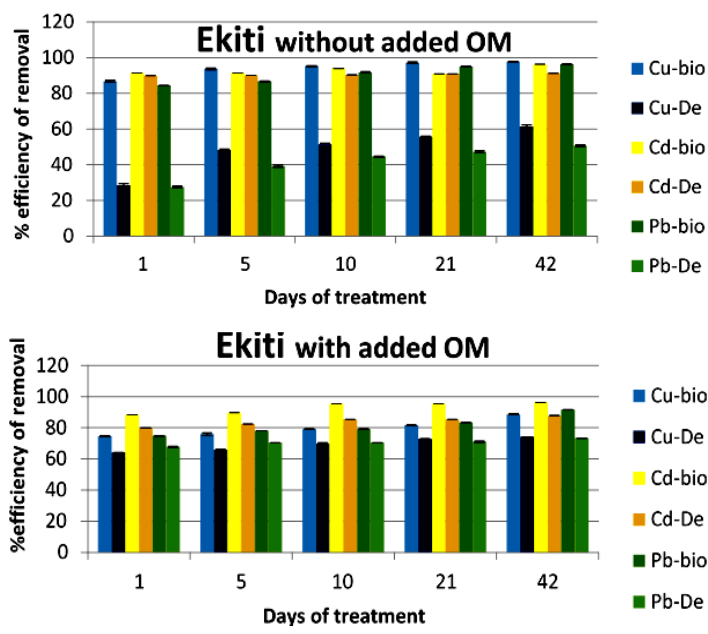

Fig. 4. Effect of organic matter on the efficiency of $2 \%(w / w)$ Biochar and $2 \%(w / w)$ Delonix regia for immobilizing heavy metals from contaminated Ekiti soil
The result in Fig. 4 are for Ekiti soil, amendment of the soil with biochar reduced the immobilization efficiency of biochar for all the metals studied, but an increase in efficiency was observed for its immobilization of cadmium only after day 5 of the aging period.

This might be due to the fact that organic ligands from humic acid prevented the sorption of metals onto the soil or/and biochar and also because the soil $\mathrm{pH}$ was reduced after the addition of humic acid. The result obtained from Ekiti soil showed that the addition of organic matter to the soil increased the efficiency of immobilization of copper and lead by Delonix regia while the removal efficiency of cadmium remained unchanged. The addition of organic matter to this soil increased the immobilization efficiency of Delonix regia for copper and lead from $50 \%$ to $70 \%$ copper and $45 \%$ to $70 \%$ lead. Soils high in $\mathrm{pH}$ and organic matter were reported by Ma et al., 1983 to retain more lead than those possessing lower values in these properties.

The plots of the results obtained from llesha soil is shown in Fig. 5, the result obtained from this soil has similar trend with what was obtainable from the study with Ekiti soil.
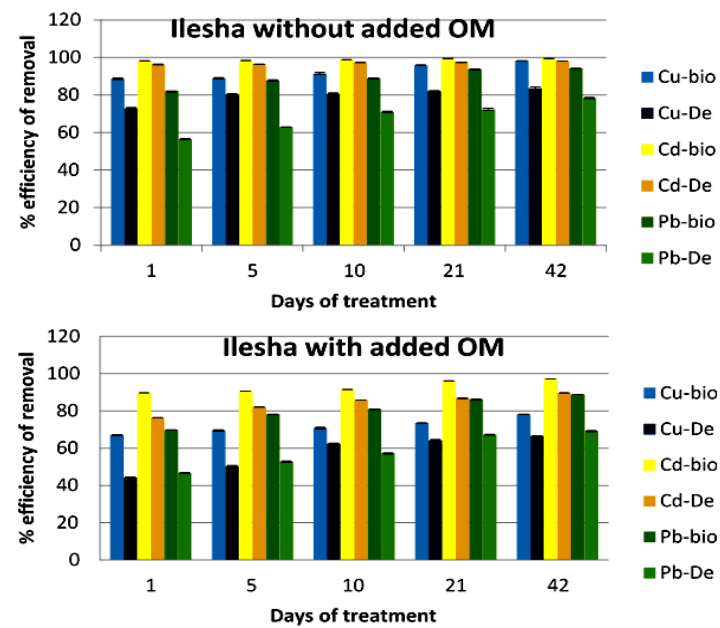

Fig. 5. Effect of organic matter on the efficiency of $2 \%$ (w/w) Biochar and $2 \%(w / w)$ Delonix regia for immobilizing heavy metals from contaminated llesha soil

The soil amended with Delonix regia but without added organic matter have moderate efficiency (an average of 50\%) for immobilizing lead and a slight increase to $55 \%$ was observed when organic matter was added. The result further 
confirmed the finding that reduced immobilization efficiency of metals onto adsorbent occur in the presence of high soil organic matter. For the two set of soils used in this study, we observed that higher \% immobilization efficiencies were recorded in soils without organic matter when the soils were amended with biochar but the presence of organic matter enhanced the immobilization ability of Delonix regia for the metals.

\section{CONCLUSION}

The study revealed that Delonix regia material could be useful as treatment in organic matter rich soils especially agricultural soils contaminated with low levels of contaminants; the opposite was observed in biochar treated soils, increased immobilization efficiency was recorded in soils without added organic matter. It thus can mean that biochar can be useful in removing metals from weathered and exposed soils. Even though the immobilization efficiency of both types of amendment increased with aging, Biochar was seen to be more effective than Delonix regia as aging increased. It revealed that biochar could be used in both low and highly contaminated soils while Delonix regia performed better in soils with low level of contamination. Soil pH played an important role in the efficiency of both types of treatment; at $\mathrm{pH} 3$ to 7 used in this study, the immobilization efficiency of Biochar was greater than $70 \%$, this is an indication that biochar could be a good treatment to use on polluted soils without restrain by soil $\mathrm{pH}$ but this was not the case with Delonix regia.

\section{ACKNOWLEDGEMENT}

Authors are grateful for the support received from the Schlumberger Faculty for the Future Foundations, Netherlands.

\section{Conflicts of interest}

We declare that there is no conflict of interest.

\section{REFERENCES}

1. Babalola, B. M., Babalola, A. O., Adubiaro, H. O., Ayanda, O.S., Nelana, S. M., Naidoo, E. B. Application of waste Delonix regia pods and leaves for the sorption of $\mathrm{Pb}$ (II) ions from aqueous solution: kinetic and equilibrium studies. Water Quality Research Journal., 2019a.

2. Babalola, B. M., Aiyesanmi, A. F., Okoronkwo, A. E., Adehanloye, M. A. Adsorption of chromium (VI) by Flame of the Forest (Delonix regia) pods: Kinetics and Thermodynamic Studies, Federal University Wukari Trends in Science and Technology., 2019b, 4(2) 602-607.

3. Bolan, N.S. and Duraisamy, V.P., Role of inorganic and organic soil amendments on immobilisation and phytoavailability of heavy metals: a review involving specific case studies. Soil Research., 2003, 41(3), 533-555.

4. Bolan, N., Adriano, D. and Mahimairaja, S., Distribution and bioavailability of trace elements in livestock and poultry manure by-products. Critical Reviews in Environmental Science and Technology., 2004, 34(3), 291-338.

5. Cao, X., Ma, L., Liang, Y., Gao, B. and Harris, W., Simultaneous immobilization of lead and atrazine in contaminated soils using dairymanure biochar. Environmental science \& technology., 2011, 45(11), 4884-4889.
6. Chan, K.Y. and Xu, Z., Biochar: nutrient properties and their enhancement. Biochar for environmental management: Science and Technology., 2009, 1, 67-84.

7. Chaney, R.L., Reeves, P.G., Ryan, J.A., Simmons, R.W., Welch, R.M. and Angle, J.S., An improved understanding of soil $\mathrm{Cd}$ risk to humans and low cost methods to phytoextract Cd from contaminated soils to prevent soil $\mathrm{Cd}$ risks. Biometals., 2004, 17(5), 549-553.

8. Chen, B. and Chen, Z., Sorption of naphthalene and 1-naphthol by biochars of orange peels with different pyrolytic temperatures. Chemosphere., 2009, 76(1), 127-133.

9. Chen, G., Zeng, G., Du, C., Huang, D., Tang, L., Wang, L. and Shen, G., Transfer of heavy metals from compost to red soil and groundwater under simulated rainfall conditions. Journal of Hazardous Materials. 2010, 181(1-3), 211-216.

10. de Barros Amorim, M.J., Römbke, J., Schallnaß, H.J. and Soares, A.M.V.M., Effect of soil properties and aging on the toxicity of copper for Enchytraeus albidus, Enchytraeus luxuriosus, and Folsomia candida. Environmental Toxicology and Chemistry., 2005, 24(8), 1875-1885. 
11. El Khalil, H., El Hamiani, O., Bitton, G., Ouazzani, N. and Boularbah, A., Heavy metal contamination from mining sites in South Morocco: monitoring metal content and toxicity of soil runoff and groundwater. Environmental monitoring and assessment., 2008, 136(1-3), 147-160.

12. Festus, A.A., Elvis, O.A. and Morayo, A.B., Equilibrium Sorption of Lead and Nickel from Solutions by Flame of the Forest (Delonix regia) Pods: Kinetics and Isothermic Study. Journal of Environmental Protection., 2013, 4(03), 261.

13. Fijałkowski, K., Kacprzak, M., Grobelak, A. and Placek, A., The influence of selected soil parameters on the mobility of heavy metals in soils. Inzynieria i Ochrona Srodowiska., 2012, 15, 81-92.

14. Ippolito, J.A., Laird, D.A. and Busscher, W.J., Environmental benefits of biochar. Journal of environmental quality., 2012, 41(4), 967-972.

15. Inyang, M.I., Gao, B., Yao, Y., Xue, Y., Zimmerman, A., Mosa, A., Pullammanappallil, P., Ok, Y.S. and Cao, X., A review of biochar as a low-cost adsorbent for aqueous heavy metal removal. Critical Reviews in Environmental Science and Technology., 2016, 46(4), 406-433.

16. Jiang, X.J., Luo, Y.M., Zhao, Q.G., Baker, A.J.M., Christie, P. and Wong, M.H., Soil Cd availability to Indian mustard and environmental risk following EDTA addition to Cd-contaminated soil. Chemosphere., 2003, 50(6), 813-818.

17. Karami, N., Clemente, R., Moreno-Jiménez, E., Lepp, N.W. and Beesley, L., Efficiency of green waste compost and biochar soil amendments for reducing lead and copper mobility and uptake to ryegrass. Journal of Hazardous Materials., 2011, 191(1-3), 41-48.

18. Konare, H., Yost, R.S., Doumbia, M., McCarty, G.W., Jarju, A. and Kablan, R., Loss on ignition: measuring soil organic carbon in soils of the Sahel, West Africa. African Journal of Agricultural Research., 2010, 5(22), 3088-3095.

19. Kumpiene, J., Lagerkvist, A. and Maurice, C., Stabilization of $\mathrm{As}, \mathrm{Cr}, \mathrm{Cu}, \mathrm{Pb}$ and $\mathrm{Zn}$ in soil using amendments-a review. Waste management., 2008, 28(1), 215-225.

20. Lanno, R., Wells, J., Conder, J., Bradham, K. and Basta, N., The bioavailability of chemicals in soil for earthworms. Ecotoxicology and environmental safety., 2004. 57(1), 39-47.

21. Louis, M.R., Sorokhaibam, L.G., Bhandari, V.M. and Bundale, S., Multifunctional activated carbon with antimicrobial property derived from Delonix regia biomaterial for treatment of wastewater. Journal of Environmental Chemical Engineering., 2018, 6(1), 169-181.

22. Ma, W., Edelman, T., Van Beersum, I. and Jans, T., Uptake of cadmium, zinc, lead, and copper by earthworms near a zinc-smelting complex: influence of soil $\mathrm{pH}$ and organic matter. Bulletin of Environmental Contamination and Toxicology., 1983, 30(1), 424-427.

23. Mandal, J., Roy, I., Chatterjee, S. and GuptaBhattacharya, S., Aerobiological investigation and in vitro studies of pollen grains from 2 dominant avenue trees in Kolkata, India. Journal of Investigational Allergology and Clinical Immunology., 2008, 18(1), 22.

24. Memon, A.R. and Schröder, P., Implications of metal accumulation mechanisms to phytoremediation. Environmental Science and Pollution Research., 2009, 16(2), 162-175.

25. Mench, M., Lepp, N., Bert, V., Schwitzguébel, J.P., Gawronski, S.W., Schröder, P. and Vangronsveld, J., Successes and limitations of phytotechnologies at field scale: outcomes, assessment and outlook from COST Action 859. Journal of Soils and Sediments., 2010, 10(6), 1039-1070.

26. Méndez, A., Gómez, A., Paz-Ferreiro, J. and Gascó, G., Effects of sewage sludge biochar on plant metal availability after application to a Mediterranean soil. Chemosphere., 2012, 89(11), 1354-1359.

27. Ok, Y.S., Lim, J.E. and Moon, D.H., Stabilization of $\mathrm{Pb}$ and $\mathrm{Cd}$ contaminated soils and soil quality improvements using waste oyster shells. Environmental Geochemistry and Health., 2011, 33(1), 83-91.

28. Onwuka, J.C., Agbaji, E.B., Ajibola, V.O. and Okibe, F.G., Kinetic studies of surface modification of lignocellulosic Delonix regia pods as sorbent for crude oil spill in water. Journal of applied research and technology., 2016, 14(6), 415-424.

29. Petruzzelli, G., April. Soil contamination and remediation strategies. Current research and future challenge. In EGU General Assembly Conference Abstracts., 2012, 14, 7963. 
30. Rieuwerts, J.S., Ashmore, M.R., Farago, M.E. and Thornton, I., The influence of soil characteristics on the extractability of $\mathrm{Cd}, \mathrm{Pb}$ and $\mathrm{Zn}$ in upland and moorland soils. Science of the total Environment., 2006, 366(2-3), 864-875.

31. Subramani, S.E., Kumaresan, D. and Thinakaran, N., Application of activated carbon derived from waste Delonix regia seed pods for the adsorption of acid dyes: kinetic and equilibrium studies. Desalination and Water Treatment., 2016, 57(16), 7322-7333.

32. Tchounwou, P.B., Yedjou, C.G., Patlolla, A.K. and Sutton, D.J., Heavy metal toxicity and the environment. In Molecular, Clinical and Environmental Toxicology., 2012, 133-164). Springer, Basel.

33. Todorovic, Z.B., Randelovic, L.M., Marjanovic, J.Z., Todorovic, V.M., Cakic, M.D. and
Cvetkovic, O.G., The assessment and distribution of heavy metals in surface sediments from the reservoir'Barje': Serbia. Savremene tehnologije., 2014, 3(2), 85-95.

34. Yuan, J.H., Xu, R.K. and Zhang, H., The forms of alkalis in the biochar produced from crop residues at different temperatures. Bioresource Technology., 2011, 102(3), 3488-3497.

35. Zhao, L.Y., Schulin, R. and Nowack, B., Cu and $\mathrm{Zn}$ mobilization in soil columns percolated by different irrigation solutions. Environmental Pollution., 2009, 157(3), 823-833.

36. Zhang, X., Wang, H., He, L., Lu, K., Sarmah, A., Li, J., Bolan, N.S., Pei, J. and Huang, $\mathrm{H}$., Using biochar for remediation of soils contaminated with heavy metals and organic pollutants. Environmental Science and Pollution Research., 2013, 20(12), 8472-8483. 